\title{
Teaching for Entrepreneurial Learning
}

\author{
Eirik S. Jenssen*, Frode Olav Haara \\ Faculty of Education, Arts and Sports, Western Norway University of Applied Sciences, Norway
}

Copyright $@ 2019$ by authors, all rights reserved. Authors agree that this article remains permanently open access under the terms of the Creative Commons Attribution License 4.0 International License

\begin{abstract}
Today's students live in a society, recognised from global perspectives, which is mobile and manifold. When they finish their studies, they will be working in a society filled with rapid changes and development, maybe in a job that do not yet exist. Faced with such a scenario, do primary and lower secondary schools emphasise the right competences? The purpose of this article is to explore how schools may develop an entrepreneurial didactics. We look at how two schools develop pedagogical entrepreneurship as a basic foundation for the school's activities, which emphasise students' entrepreneurial learning. The two schools invest in the active, critical and creative students who take responsibility together with others. They want the students to be resources of their local environment, and to have the opportunity to develop competences that are viable in the future. Students' co-determination, relevance and trust are identified as key elements in their development of teaching for entrepreneurial learning.
\end{abstract}

\section{Keywords Pedagogical Entrepreneurship,} Entrepreneurial Didactics, Entrepreneurial Learning, Teaching, School

\section{Introduction}

Society is changing at a fast pace, and we are seeing a trend in which work is being performed more efficiently, the need for formal education is increasing, and new occupations and workplaces are continually developing. According to the World Economic Forum, 65\% of children starting school today will work in industries and jobs, which do not yet exist (WEF, 2016). The World Economic Forum is also launching a list of 10 skills, which are likely to become more important than others in the future. At the top of this list are complex problem-solving, critical thinking and creativity, and we also find several connections to cooperation and the ability to relate to other people (WEF, 2016). Current and future students should feel that they are going to a school, which prepares them to live and work in the society of the future, and it is pertinent to question whether current schools are developing these qualities and skills well enough.

Pedagogical entrepreneurship is concerned with developing certain entrepreneurial skills and attitudes that makes pupils more self-reliant and better equipped to handle life (Gibb, 1993). Pedagogical entrepreneurship entails the use of teaching methods, which give students authority and activate learning awareness. It requires working methods which improve students' creative abilities and belief in their own skills, and which provide a basis for seeing the opportunities around them and the motivation to become drivers for development in the community. When the term pedagogical entrepreneurship is used in a lifelong learning perspective, it is understood to be the formation of a life cycle in which creative and active methods of learning form a central part. A focus on entrepreneurial learning thus becomes a prioritisation in terms of processes, products and working methods in school subjects (Haara \& Jenssen, 2016).

Entrepreneurial learning has much in common with other pedagogical approaches with a long tradition in schools, such as problem-based learning and project work, but also has some unique characteristics such as prioritising the ability to see opportunities, work innovatively and demonstrate a certain willingness to take risks (Lackéus, 2015). Entrepreneurial learning can be prioritised both in and across subjects, both by employing known working methods and developing new ones (Sagar, 2014; Haara \& Jenssen, 2016), and is thus a perspective for the work in schools, which addresses many of the challenges highlighted both by sociopolitical parties (European Commission, 2010, 2013; European Council, 2000) and research into creativity and education (Dweck, 2006; Sawyer, 2012). Against this background, we ask: How can schools develop an entrepreneurial didactic? We have done this by looking into how entrepreneurial aspects are expressed in two schools, which market themselves as entrepreneurial in their approach to the subject matter.

\section{Theoretical Basis}

Rapid developments in society have not been echoed by equivalent developments in the education sector. In a broad 
review of literature looking into the need for changes to the school system, there are, according to Keith Sawyer (2012), two main arguments, which are repeated:

- $\quad$ There are many children who do not do well at school.

- Schools are not suitable for the life which children will live in the 21 st century.

Educational systems all over the world need to understand and accept the consequence of the fact that not all children are equal, that they learn in different ways and at different speeds and that they have different interests, strengths and weaknesses which the school must take into account, (Thomson, 2012). Learning cannot be regarded as a linear process, but as something, which takes place in different contexts, and schools must focus more on varied forms of learning which prioritise metacognitive learning strategies (Thomson, 2012).

Sawyer (2012) refers to the need for sweeping changes whereby schools must develop resources, tasks and pedagogical methods, which help a greater proportion of students to meet the requirements set by schools and society, and to the fact that the schools must focus on activities, which promote social learning and motivation and on work that creates meaning. Stimulation and the development of creativity are the key element of this work. So what does creativity involve? There is a broad consensus among creativity researchers that creativity does not involve one but several different mental processes. It tends to revolve around a problem that must be expressed, and the relevant knowledge obtained. Creativity is always based on mastering a problem, gaining experience and expertise. Creativity is often the result of an awareness that is unexpected and apparently irrelevant information can be of great importance. It is important that time and space is allowed for the incubation phase, in which ideas and combinations of ideas can develop, before the ideas are selected and externalised (Sawyer, 2012).

Research has identified a number of personality traits, which are associated with a high degree of creativity. Highly creative individuals seem to combine a wide range of often apparently contradictory qualities in a complex mix. Amabile $(1983,1988)$ emphasises the importance of broad personality factors, such as task motivation - there must be something in the situation that is felt to be engaging, challenging, provocative or unsatisfactory, domain-specific knowledge and skills - this need not be fully in place before the creative process takes place, but can be developed in parallel with the other factors, and knowledge and skills relevant to creativity and innovation - imagination, curiosity, self-confidence, the ability to live with uncertainty and cope with failure, perseverance, willingness to cooperate, etc. Traditionally, these qualities have not been recognised at schools to any great degree. Studies have shown that students' behavior, which teachers tend to perceive as problematic involves the very qualities, which according to creativity research have been found to correlate positively to creativity. These concern qualities such as a degree of stubbornness, criticality and non-conformism (Andiliou \& Murphy, 2010; Beghetto, 2007; Karwowski, 2007; Kennedy, 2005; Runco \& Johnsen, 2002; Sternberg, 2006; Westby \& Dawson, 1995). Students whom teachers like least appear to be those who score most highly on a number of qualities associated with creativity. Studies also show that it is rare for teachers to reward creativity in the classroom (Sawyer, 2012).

Sawyer (2012) has emphasised six findings from international creativity research which he believes are of particular relevance to schools.

1. The most common is that creativity is the result of deliberate and prolonged hard work. When 'sudden insights' occur, these have a tendency to represent only small amounts of progress, in an ongoing creative process, towards a solution. These insights almost always prove to involve combinations of previous experience and research.

2. Most creative innovations mean breaking at least one established 'rule'. However, in order to break rules constructively and productively, one must know the rules and understand something about which ones it could be worth breaking. According to Sawyer (2012), the type of surface knowledge that is a result of much of the teaching taking place in schools at the moment is not enough. Creativity is a result of detailed knowledge and understanding, which requires a highly focused and active form of learning.

3. Although creative contributions generally come from people who have a deep type of knowledge within an area, it is a fact that these people often also have good knowledge of other areas, from which they take ideas and inspiration - known as 'cross-fertilisation'.

4. Groups are playing an increasingly important role in creative work, and creative solutions are often the result of conversations and discussions in groups. At the same time, research shows that creative individuals often have a strong need to switch between specialising as individuals and generating group-based impulses and processes.

5. The more radical the new ideas are, the more resistance one must be prepared to encounter.

6. Rather than revolving around stable personality traits, creativity revolves around specific strategies that are contingent on situation. Although there are certain personal qualities and dispositions which appear to correlate with the degree of originality, research is fairly unanimous that much of creativity is something that can be learned. The earlier this learning begins, the better it will be.

A consequence of this is that creative learning in schools should not be reserved for the so-called practical-aesthetic subjects, but should form part of approaches and working methods in all subjects at student, class and school level (Wiggins, 2012). He claims that creative learning has only taken place if students can later use what they have learned in order to make a difference for the better. Against this 
background, Wiggins sees creative learning as the opposite to 'boring learning' and 'unfruitful learning' (Wiggins, 2012: 321). According to Wiggins, schools will continue to be ineffective and uninteresting for a majority of students until they offer them an education, which has creative learning as the objective in all subjects. According to Wiggins, creativity is just as necessary for breaking through the defence in a football match in a PE lesson, for solving mathematical problems in a maths lesson, or working with complex scenarios regarding historical problems or contemporary challenges in a social science lesson. This is something that must be learned at school. The American Committee on Developments in the Science of Learning (CDSL) emphasises the importance of giving students the opportunity to use knowledge and skills in varied and new situations: 'Transfer can be explored at a variety of levels, including transfer from one set of concepts to another, one school subject to another, one year of school to another, and across school and every day, non-school activities (CDSL, 2001, p. 235).

A review of international research performed by Sawyer (2012) shows that a relatively high number of lists have been drawn up activities and teaching methods which promote creative thinking and behaviour. The following recommendations are made in many of these lists (according to Sawyer, 2012):

- Openness: Expect and encourage unexpected questions and ideas.

- Evaluation: Allow students to do something without evaluating them; teach and assess creativity. Ensure that tests and exams contain questions which require creative thinking; reward and praise creative ideas and results.

- Safety: Ensure that there is a safe and supportive learning environment.

- Build self-confidence: Tell students that they have what it takes to be creative, help students to be aware of their own creativity.

- Help students withstand the pressure to conform: Allow students to be different.

- Problem identification: encourage students to identify and refine problems. Encourage different responses, humour and willingness to ask questions and take chances.

- $\quad$ Be a role model for creativity: Teachers should demonstrate different ways in which one can identify, reformulate and solve various problems.

- Make assumptions and prejudices relevant: Get students to formulate and question previously stated assumptions, mindsets and 'things that are taken for granted'.

- Encourage the generation of ideas: Ask open questions and give students time to come up with several possible answers. Encourage and reinforce students' original ideas.

- Encourage 'cross-fertilisation': Give students the opportunity to think across academic subjects.
- Provide space for incubation: Give students time to think about and develop their creative ideas.

- Allow mistakes and use them as the basis for new learning.

- Empathise with the viewpoints of others: encourage students to adopt other perspectives.

- Motivate students to master basic knowledge and skills, and emphasise that these are an essential basis for creativity. Emphasise that hard work and perseverance are just as important as talent. Stimulate in-depth learning.

- Adopt an inclusive approach in which the class works together to identify and solve problems, and discuss and think things through together.

According to Sawyer (2012), the greatest barrier to adopting this type of teaching is that we do not have time, because we must get through the syllabus: 'the curriculum is sometimes said to be a mile wide and an inch deep' (Sawyer, 2012, p. 401) Within creativity research, there is broad agreement that although there are general strategies, knowledge and skills with regard to creativity, creativity is largely domain-specific (Amabile, 1990, 1996; Baer, 2010; Chappell, 2007; Craft et al., 1997; Cremin \& Barnes, 2010; Sawyer, 2012; Vass, 2004). In accordance with these findings, it can be argued that creative learning should be integrated in all school subjects.

\section{Methods}

In order to study how schools can develop an entrepreneurial didactics, we have endeavoured to identify characteristics of two schools which over time have focused on pedagogical entrepreneurship and which describe themselves as entrepreneurial. For this work, we have adopted a case study approach using qualitative tools (Merriam, 1998; Yin, 2014). The central objective has been to identify an entrepreneurial didactics in the two case schools, and we have adopted a broad approach in order to help create the insight, which will enable us to discuss and draw conclusions in relation to the research question we are asking. We have interviewed students, teachers and head teachers. We have read and analysed planning documents and websites, and we have observed a range of teaching programmes.

A case can be described as a phenomenon, which takes place within a defined context (Merriam, 1998). With regard to research based on case studies, Merriam (1998) regards a qualitative case study as a comprehensive description and analysis of a defined phenomenon such as an institution, person, process or social unit. In line with Merriam's (1998) interpretation of a qualitative case study, we regard our studies of two strategically selected primary and lower secondary schools as a case study, in which the phenomenon studied is that some schools have developed an entrepreneurial didactics, and that through data and analysis, we are able to study the basis of this development 
and highlight the importance of focusing on this kind of didactics in schools.

\subsection{Document Studies}

Several documents were obtained from the two case schools. These concern municipal plans, and plans developed at each of the two schools. In this project, we have also used both schools' websites and Facebook pages. The digital channels are used actively by the schools in order to present the schools and inform the outside world of activities organised by the schools.

\subsection{Interviews}

The interviews form a central part of the basic data. Since the two case schools consider themselves to be schools which work in an entrepreneurial way, it is interesting to obtain their understanding of what makes the schools entrepreneurial, how they understand their role in this work, and how they experience the freedom of action available to them. We have interviewed three different groups: teachers, head teachers and students.

At each of the two schools, it was the head teacher (rector) who selected two teachers for individual interviews. The head teacher also selected students for the group interviews.

We decided to ask the head teachers and teachers virtually the same questions, since we wanted them to talk about the same aspects of pedagogical entrepreneurship. With regard to teachers and head teachers, we decided to focus on these four sub-areas, which form separate parts of the interview guides:

Table 1. Sub-area - teachers

\begin{tabular}{|c|c|}
\hline $\begin{array}{c}\text { Sub-goal } \\
\text { areas }\end{array}$ & Operationalisation of research areas \\
\hline Beliefs & $\begin{array}{r}\text { How do teachers understand their role in relation to } \\
\text { pedagogical entrepreneurship? }\end{array}$ \\
\hline Staff & $\begin{array}{c}\text { How do teachers work together on pedagogical } \\
\text { entrepreneurship at the school? }\end{array}$ \\
\hline Framework & $\begin{array}{c}\text { How do teachers understand key governing } \\
\text { documents regarding the school's activities, in terms } \\
\text { of entrepreneurship? }\end{array}$ \\
\hline Teaching & $\begin{array}{c}\text { How do teachers facilitate pedagogical } \\
\text { entrepreneurship in their subjects? }\end{array}$ \\
\hline
\end{tabular}

Table 2. Sub-area - head teachers

\begin{tabular}{|c|c|}
\hline $\begin{array}{l}\text { Sub-goal } \\
\text { areas }\end{array}$ & Operationalisation of research areas \\
\hline Beliefs & $\begin{array}{l}\text { How does the rector understand their role in relation } \\
\text { to pedagogical entrepreneurship? }\end{array}$ \\
\hline Staff & $\begin{array}{l}\text { How does the rector lead pedagogical } \\
\text { entrepreneurship at their school? }\end{array}$ \\
\hline Framework & $\begin{array}{c}\text { How does the rector understand key governing } \\
\text { documents regarding the school's activities, in terms } \\
\text { of entrepreneurship? }\end{array}$ \\
\hline Teaching & $\begin{array}{l}\text { How does the rector see their position in terms of } \\
\text { prioritising pedagogical entrepreneurship at their } \\
\text { school? }\end{array}$ \\
\hline
\end{tabular}

The questions were open and generally designed to encourage the informants to talk about how pedagogical entrepreneurship was handled at their school. The subject was familiar to the informants, and they demonstrated a high degree of enthusiasm, and presented numerous stories and practical examples to illustrate their thoughts.

Three focus group interviews were also held with a total of 14 students in the 10th grade. Group-based interviews can in some cases provide more information than individual interviews. The researcher can play on the interaction between participants, and the dynamic process between the participants can provide the opportunity for several people to respond to an individual's input, allowing descriptions to be elaborated on or reinforced. It thus becomes possible to gather a great deal of information in a limited time. The students in this survey are in the same class and know each other. This can be both an advantage and a disadvantage. The advantage is that they can feel safe with each other, but if the students have poor relationships with each other, it can be uncomfortable for them to be open in interviews. Consequently, respondents' behaviour may be conformist and they may withhold their views. Krueger and Casey (2015) warn against choosing close friends for focus group panels, since they will often provide less information and tend to have a leader who dominates the discussions. We found that there was a difference between the three focus groups. One group was extremely active and provided an abundance of examples and viewpoints, while the other two groups were more reserved and provided brief and not very detailed information. In all the groups, there were some students who dominated the discussions, and to some degree we had to use our role as moderator to bring the other participants in with descriptions and exchanges of opinions.

Each interview lasted around 60 minutes, and was recorded on a dictaphone and later transcribed. The content was analysed and categorised in view of the problem. We used phenomenological condensation of opinions (Kvale \& Brinkmann, 2015) as a basis, in which analysis work is performed in various phases. In the first phase, the transcribed interviews were read with the aim of obtaining a full impression of the material. In the next read-through, we attempted to identify opinion-forming units in each interview and across the interviews. These were then compared in a new matrix in which the condensed opinion/information from each informant was included for all of the questions.

\subsection{Observations}

As well as obtaining written and verbal data, the two schools contacted us when they would be carrying out a teaching project, which they described as entrepreneurial. We observed without getting involved in the teaching projects. 


\subsection{Analysis}

We regard the phenomenological condensation of opinions, which we performed on the interview data (Kvale, Brinkmann, 2015) to be part of the constant comparative analysis method (Glaser, 1965; Strauss \& Corbin, 1998) which we have used for the study of the two case schools. We worked in four phases with the full analysis work:

- Comparison of impressions and incidents in categories

- Comparison of categories and their qualities

- Delimiting the interpretation and understanding based on a summary of the categories and their qualities

- Describing the interpretation and understanding as a basis for discussing the study's research question and highlighting the significance of a focus on this kind of teaching in schools.

The constant comparative analysis is an analysis method, which assumes that there is a continuous flow from phase to phase, but that all phases are operational throughout the full analysis process and contribute to the development of the subsequent phase, until the analysis ends (Glaser, 1965). In this study, that means that new types of data continuously contributed to ensuring that the full analysis of the case schools' teaching with the aim of entrepreneurial learning was further refined through an interaction between deduction and induction. New data were seen in conjunction with previously collected and analysed data, and both influenced the analysis of these and were themselves influenced by these when they were analysed and seen in context with the prevailing interpretation and understanding. Later in the article, this will be connected to each of the schools and then to the question of how schools can develop an entrepreneurial didactics.

\subsection{Validity and Reliability}

This study is based on qualitative data in which we as researchers participate actively in the construction of the data. It is therefore important to reflect on the validity and reliability of the study, and on the durability of its results.

In this study, we have attempted to reinforce the validity in several ways. Through a semi-structured type of interview, we aimed to facilitate an open dialogue between interviewer and informant, in which it is possible to correct perceptions during the interview by asking concluding questions. We have subsequently also made response validation a priority, by allowing the informants access to the interview texts for comments. The head teachers have also read the presentation of the results for their school (i.e. their school's part of the section 'Findings') and could provide comments, which has given the schools the opportunity to add to the texts afterwards with reflections.

Reliability is connected to the dependability of the survey, and the fact that there is a correlation between what the researcher reports and what is taking place within the phenomenon, which is being studied. Intersubjective control of the analysis process, with more than one of the researchers evaluating and interpreting the same material, can ensure reliability in terms of drawing credible conclusions. We have also attempted to ensure validity and reliability by presenting a detailed and thorough review of the various stages of the research process, thereby giving the reader the opportunity to investigate both the assumptions and conclusions.

\section{Findings}

\subsection{School 1}

School 1 is a small school with mixed-age classes for students from the first to the tenth grade, and it also has a kindergarten. The school has a long tradition of working with small numbers of students and mixed-age teaching. It involves planning for three-year periods, and it is not possible to use textbooks in the same way as bigger schools with single-year classes can. It means that the teachers are used to thinking creatively and designing their own teaching projects. In broader terms, the school is very focused on students in various elements of its teaching and giving them plenty of space to work on a range of topics.

The rector explains that students who are not used to working in an entrepreneurial way (with open tasks, problem-solving, cooperation, a flexible framework) often struggle when given such assignments. The rector emphasises that it is important to start giving students space early and training them in skills and attitudes related to innovation and creativity. At School 1, working methods have been implemented which are designed to develop students' independence, which also requires teachers to have the courage to let go of control to some degree, and to trust students and give them responsibility. There are four categories in particular which appear in the entrepreneurial work at this school: variation, creativity, real-life assignments and value creation for oneself and others.

\subsubsection{Variation}

Variation is a key term, which is repeated through the data material, both in terms of working methods and learning arenas. The teachers describe that different students thrive in different arenas, and that this brings benefits at several levels. One teacher expresses it like this: '(...) there are many students who are stronger outside the classroom than inside the classroom. They accomplish things; they demonstrate more and different types of knowledge. They thereby develop a belief in themselves (...) and the students develop respect for different qualities and knowledge. This teacher describes that variation in learning arenas helps to build a more inclusive learning environment, in which all students have more space to 
participate in and form an active part of the community. Students are also happy that the teaching is varied, and they believe that they learn better from this. The students mention several subjects in which they work in a problem-oriented way and in which they are given open tasks without a clear or set answer. They have to discuss them with their fellow students and sometimes have to bring in knowledge from other subjects in order to solve a challenge. The students say that these tasks are motivating and one student says that 'you feel a bit cleverer because you get to show what you know and how well you understand knowledge from other subjects'.

The rector and teachers are aware that it is the competence goals that should control activities in the school, rather than the textbooks, and that the teachers must be given plenty of space to structure their teaching in the way that they feel best. Some of the variation can relate to practical tasks, such as building shelters or model boats. It is interesting that the students also express the connection between subject and activity, when they describe that they learn a lot of maths and Norwegian when they build a shelter, as well as the ability to cooperate, through discussions and focusing on a solution. The students say that when they use knowledge in practical work, they remember it better and see the relevance of it.

\subsubsection{Creativity}

The students describe that they often use working methods in which they have to be creative. This could involve working with the subject matter in a particularly investigative way involving the use of digital tools and a range of applications. They describe that they often make short films in different subjects. The films become the students' product after working on a topic. Teachers and students both emphasise that the work must have an academic basis, but that the angle can take the form of something that more closely relates to the students' life world. This could involve presenting historical incidents using modern media channels, e.g. a news report about the Napoleonic wars. The students express that this is motivating, fun and educational. Connecting film to the subject in this way activates the students and makes it almost impossible to be passive.

\subsubsection{Real-life Assignments}

Real-life assignments means getting students to work on tasks, which relate to real problems around them, as opposed to constructed challenges in textbooks. School 1 is highly visible in the local community and works well with various institutions and companies. The students describe that they were contacted by a local company asking whether they could make a film about a new product, which the company could put on its website. They were also contacted about teaching the students in a nearby school in the creative use of digital tools. It is clear that the students are proud of these events, and that the significance of being seen as a resource encourages motivation and engagement. Another real-life assignment was developed in partnership with a local waste and environmental company, and concerns recycling and reducing residual waste. Here, the school is working on researching whether certain measures increase the level of recycling. It involves formulating problems, weighing plastic bags, keeping statistics and writing reports. This kind of project encourages interdisciplinary work.

\subsubsection{Creating Value}

Working in an entrepreneurial way largely involves creating values for oneself and for others. In this context, values must be interpreted broadly, and School 1 works on a number of types of value creation. The students at the school demonstrate responsibility for the environment, for example by clearing plastic from the shoreline, relational value by visiting a retirement home, and financial value by donating the profit from the students' company to worthy causes. One student describes it like this: '(...) last year we gave money to some people who wanted to have a school in Tanzania. And we were the ones who decided where the money should go. We have also written letters to the young people in Tanzania, and have received letters back from them. That was really cool. We think that it is really cool that we can give something to people who need it'.

\subsection{School 2}

School 2 is a school with students from the seventh to the tenth grade, with two parallel classes for each year. For many years, the school has prioritised pedagogical entrepreneurship, and has developed a comprehensive plan for entrepreneurial teaching, which is readily available on the school's website. The school's vision is based on pedagogical entrepreneurship, and says that the school must be a resource in the local community and that the local community must be a resource in the school. It works towards this vision through four key concepts: identity, cooperation, creativity and action.

\subsubsection{Local Identity and Cooperation}

The entrepreneurial is clearly expressed in how the school emphasises the development of a local identity in its students. Developing this kind of identity means that the students must get to know themselves, their strengths and opportunities, and also gain knowledge and familiarity with the opportunities of the local area. Bringing the local community into its teaching is the characteristic of School 2. It is reflected in the school's plans, partnership agreements and teaching. In practice, it is implemented by inviting various parties into the school or arranging for students to visit businesses, various organisations or public enterprises. A teacher explains that an awareness of what the rural community has to offer in the past and present gives the students identity, pride and potentially future 
plans: 'They could actually think that perhaps there is a job here'.

Collaboration at various levels is a characteristic of the work in School 2. There is collaboration between students on tasks, collaboration with key players in the local community, and there is international collaboration. Collaboration is highlighted by the teachers as an important element of the entrepreneurial. One of them says that through collaborative processes, the students discover that they themselves are not enough, and that other people can provide good input. And at School 2, they also have their own exercises designed to practise collaboration.

Collaboration with parties in the local community forms an important part of the teaching at the school, and helps to provide insight into authentic problems. Through topic-based work and project work, work placements and teaching, students gain experience in working with national curriculum goals in a range of learning arenas, and this could help them to see connections between various topics and subjects. On other occasions, teaching involves developing students' understanding of democracy, participation and co-determination, for example by observing a municipal council meeting in which issues that are relevant to young people are discussed. School 2 has practised international collaboration since 2003 through various Erasmus projects. The rector says that collaborating across national borders and with other cultures provides useful experiences and probably a greater awareness of their own values and traditions.

\subsubsection{Creativity and Action}

Teachers and the rector all point out that students must be given tasks which give them space to develop creativity and which require more than factual knowledge, and that these are the qualities, which will be more in demand in the future. There must be space to try and fail, and try again. It is often about being able to use knowledge from one area in a different context. The school also facilitates the explicit training and practice of creativity through a range of exercises. It also puts on an annual entrepreneurs' day, with Ungt Entreprenørskap (a member of the international organisation Junior Achievement), at which students perform a range of creativity exercises.

The teachers point out that it can be a challenge for some students to work in an investigative way, and that this could be due to what they have become used to in their first six years at school. One teacher described that students who are not used to being challenged, activated and encouraged to make their own choices and students who do not want to have an opinion on something and who often reply 'don't know', can find entrepreneurial working methods challenging. The teacher believes that 'in those cases we have to set the bar lower and support them as they are'. However, it is apparent that for many students lacking confidence, it is a useful learning experience to observe the process through others, even though they are not that active themselves. The school emphasises that creativity must be expressed in action. In the school's vision, it says that 'the future needs active and engaged people who can become active employees and community builders'. At School 2, the emphasis is on training students to take the initiative and demonstrate drive. This is expressed through several realistic situations, not least partnerships with the local community.

By working in an entrepreneurial way, the school wants to give students specialist knowledge, identity, the ability to collaborate, creativity and attitudes such as intrepidity and an awareness of their responsibility. These are described as skills with no date stamp.

\subsection{How to Develop an Entrepreneurial Didactic?}

Although School 1 and School 2 are different in terms of size and age level, they have several features in common. Over time, both schools have developed good collaborations with a number of teams, organisations and businesses in their local communities. This makes a major contribution to making teaching at the school practical, varied and relevant. The rectors and teachers all make it clear that their use of the local community is linked to subjects and competence goals in the national curriculum, and that using the local community as a key learning arena is in many cases superior to textbooks.

Another feature that the schools have in common is their objective that in the long term students will return to their home community, settle and contribute to the development of the local community. The rector of School 1 says that it is therefore important to 'train the students to take responsibility, get involved, and be active citizens who have initiative'. Teachers and rectors emphasise that it is important to have enthusiastic teachers who can act as models for the students. The teachers also expressed that they belong to a supportive community in which there is a widespread culture of sharing.

During the interviews with the rectors and teachers, it becomes apparent that working entrepreneurially tends to be connected with giving up some control, and that as a teacher, one does not always have all the answers at hand. It was pointed out that there must be a great deal of headroom, and that one must not be afraid to try something one has not tried before, even though it could mean that things do not go completely according to plan. One teacher says that if you as a teacher are reliant on textbooks, then you are creating an obstacle for yourself, which can make it difficult to see opportunities. And the ability to see opportunities is highlighted as the very factor that should characterise students leaving School 1 and School 2. This objective is at least as important as exam results. One teacher expresses it like this: 'The aim is to have young people who are confident, who will dare to go out into the community, think innovatively and do something different, because that is where we want to go, that is our aim, not the 
exam'.

Our impression is that the teachers direct their attention at the students' inner drive and try to stimulate it. It means that one can start with students' interests and strengths, which in practice could mean connecting maths teaching to e.g. manipulatives or a construction project. Material dimensions, load-bearing capacity and the calculations one performs as a carpenter form the basis of maths exercises, thereby creating a motivation and relevance, which engages a group of students. And when students master a skill or solve a problem, they feel a sense of belonging.

\section{Discussion of Pedagogical Entrepreneurship in the Schools of the Future}

In this section, we will discuss the ways in which schools can develop an entrepreneurial didactics. We achieve this by discussing what characterises learning, teaching and leadership through pedagogical entrepreneurship.

\subsection{Students' Learning through Pedagogical Entrepreneurship}

Globalisation and technological developments have led to the creation of professions, which more than ever before require collaboration, flexibility, initiative and interdisciplinary problem-solving (Hofstad, 2012). In this picture, international education researchers have claimed that schools are based on outdated thinking and are not suitable for the life that children will lead (Sawyer, 2012; Thomson, 2012). The case schools in this study believe that their way of working with pedagogical entrepreneurship works by stimulating the development of qualities, which will be in demand in the society of the future. They have an emphasis on working methods in which students become involved and play an active role in their own learning, for example by using modern frames of reference to look at topics from a different era. Facilitating investigative and creative abilities in their work with academic material to which teachers do not have set answers stimulates co-creation and a dynamic approach ('growth mindset') (Dweck, 2006).

The entrepreneurial working method makes demands of students and gives them authority. Their voice and form of expression are accommodated. A student group relates that they often work with problem-solving exercises and have to work together in order to arrive at different proposed solutions, and they say that it is motivating for them to bring in knowledge from other subjects, and that this makes them feel cleverer and allows them to demonstrate what they know. By applying knowledge, students learn more, develop an ability to change and become more motivated. One teacher expresses it like this: 'the students learn, they do not merely remember'. The working method also has a motivating effect on the students. In their schooling, they find that their voice is heard and that they become involved in all aspects of the teaching, that their creativity is stimulated and that investigative and scientific approaches are facilitated. What we have called 'real-life assignments', in which students work with real assignments from institutions and businesses, are particularly well received. This applies both to School 1 and School 2. The schools want to be a resource, and this means that they must give students space and responsibility to try out their knowledge in practice, or acquire it through practice (Wiggins, 2012).

A key element of pedagogical entrepreneurship in the case schools is about being open to the outside world and utilising the resources to be found in the school's local area. The schools want to be a resource in the local community, and want the local community to be a resource in the schools' teaching. This means that the students are taught in a diversity of learning arenas in which different professions and resource persons participate. This can help to ensure that knowledge is not seen as something that is isolated to its subject, but as something that creates integrated and rich learning opportunities (Thomson, 2012). The schools focus on building a local identity, both for the school and for the students. Both of the schools say that one of their objectives is for the young people to come back and settle in their home community, and that they must therefore be aware of the opportunities to be found there. Examples from the schools indicate that use of the local community and 'real-life assignments' probably promote knowledge transfer and strengthen the students' ability to change (CDSL, 2001).

Considerable elements of pedagogical entrepreneurship is about creating values for oneself and others (Lackéus, 2016; Sagar, 2014). Both of the case schools emphasise the importance of this stance in entrepreneurial work, and ensure that it is a natural part of school life. By focusing on this perspective, students are given a role in which they are important. What they do affects more people than themselves, and it can give them a sense of achievement, whether that is about reading to the youngest children in the kindergarten, tidying up common areas or setting up a café in order to raise funds for a worthy cause. It also sends a strong signal that the here and now situation is important. Martin Lackéus (2013) points out the fact that we become more motivated by creating value for others in 15 minutes than creating value for ourselves in 15 years. This makes it possible for students to develop skills and mindsets that can turn creative thoughts into action. This in turn leads to how schools can make it possible for students to develop the type of knowledge and skills that will be required in the future.

\subsection{Teaching for Entrepreneurial Learning}

If students are to be given the opportunity to learn through pedagogical entrepreneurship, this must be 
facilitated. Based on our findings, we can highlight some characteristics which typify the teaching in both schools, and which are a key part of the work on pedagogical entrepreneurship.

\subsubsection{Student Co-determination}

One of the cornerstones of pedagogical entrepreneurship is the active student. This does not just mean being active in terms of performing, but also in terms of initiating and developing. It means that students must be given real influence in certain elements of their teaching. A challenge, which also became apparent in this study, is that working methods with a high degree of creativity, openness and problem-solving are not equally easy to all students, particularly if one is not used to this working method. However, creativity and problem-solving can be learned, and Sawyer (2012) point out that the earlier one starts, the more likely one is to be able to handle such challenges. At School 2, students start in the seventh grade, which means that the school does not have the same opportunity to focus on entrepreneurial working methods from an early age for example School 1, which has its students from the first to the tenth grade. School 2 tries to compensate for this through measures such as exercises in problem-solving, collaboration and creativity, and through working with Ungt Entreprenørskap. In other words, entrepreneurial qualities must be cultivated and nurtured if they are to develop. If a student is to benefit from working in a group, that student must over time be given the chance to learn to work in a group. If a student is to see the value in working with a scientific approach (problem-solving, investigation, obtaining data, analysis, results, reflection) and in being able to work at solving problems (analysis, planning, implementation of the plan, looking back), that student must be given the opportunity to work with such processes, with a gradually increasing degree of complexity. A student does not develop their investigative and creative skills by having a problem reduced to the reproduction of facts, or a problem reduced to an exercise. An entrepreneurial approach requires teachers to have the courage to relinquish control somewhat, which is emphasised by the rectors, and open up to investigative and creative working methods, in which students get to participate according to their ability. Through observation, we saw examples of authentic problem-solving at the case schools, where teachers speculated and investigated alongside their students.

Pedagogical entrepreneurship emphasises the importance of students' creativity, the ability to change, need to explore, problem-solving skills and the ability to collaborate. These are characteristics, which to some degree break with traditional teaching practice, which means that it can be a challenge for some schools to facilitate them. Extensive research has shown that qualities associated with creativity and independence (a degree of stubbornness, criticality and nonconformity) are perceived as challenging and problematic by teachers, while the traditionally polite and compliant ideal student is not well suited to the development of creativity (e.g. Beghetto, 2007; Moran, 2010; Scott, 1999).

Keith Sawyer (2012) points out that one of the biggest barriers to the implementation of this type of teaching is that teachers do not have time, because they have to get through the entire syllabus. At the case schools, their focus is not on having the entrepreneurial aspects as something supplementary, but on using them as a way of working towards their competence goals. The emphasis on the entrepreneurial aspects does not mean that the teaching lacks structure, guidance and control. Quite the reverse, the case schools express that involving students in various elements of the teaching improves their motivation and learning outcome.

\subsubsection{Relevance}

Another factor, which should be emphasised by schools, which want to facilitate learning through pedagogical entrepreneurship is relevance (Sawyer, 2012; Thomson, 2012; Wiggins, 2012). Most things are motivating to work with if one regards it as meaningful to invest one's time and energy in them. The issue of relevance tends to be expressed in the classroom through students' questions such as: 'Why are we learning this, teacher?' This tends to express the fact that one cannot see the significance of the knowledge or understand how it can be utilised. In a school with unidisciplinary, theoretical and fragmented knowledge, it can be difficult to see the relevance of the knowledge, at any rate beyond the particular subject. Emphasising the importance of co-determination, action, problem-solving and the multidisciplinary approach, which typifies the entrepreneurial working method, can make it easier to see potential applications of the knowledge (Thomson, 2012; Wiggins, 2012). An example of this is when the students in the study use mathematical knowledge and when they need to calculate material dimensions and load-bearing capacity for the construction of a shelter.

Both case schools emphasise that students must perceive that they make a difference in the local community, that they are perceived as a resource. To some degree, this kind of work can coincide with real challenges which the local community is facing, known as 'real-life assignments' in which the students' skills are sought and they become involved as real value creators. Opportunities like this tend to occur by chance, through students' input, the teacher's understanding of the opportunities is available, or the head teacher's encouragement, facilitation and trust in teachers and students. In this study, several examples were seen of how this was done at School 1 and School 2, and how with steadily increasing complexity and quality, the students work on investigation, scientific approaches, reporting and communicating. 


\subsubsection{Trust}

A third factor, which we would like to mention as a vital part of teaching with the aim of entrepreneurial learning is trust. All the parties involved in a school's work rely on trust. This means all the parties is given trust and showing trust. For head teachers, it means having a predictable attitude to the work performed by students and teachers, and reacting to initiative and thoughts on content, organisation and activity with confidence. Teachers must also have the ability to see opportunities rather than difficulties. It is about giving students the tools to utilise opportunities well and creatively. If students are to experience a real sense of co-determination, they must know that they have the opportunity to have influence, and they must feel that they are trusted within the framework that has been set out.

Teachers must also feel that they are trusted by their head teacher. The safest thing for many teachers is probably to 'teach by rote', which means not straying from the textbook, but according to research, students are working very little with the skills that will be in demand in the future when they are looking for set answers or reproducing factual information about a subject from a text. Trust is not built through constant reminders of a controlling nature, for example, through quizzing the students on their homework or through tests which reproduce facts. However, by realising and experiencing the content that one has chosen to prioritise, the way in which one has chosen to present or communicate, and the interpretations or arguments one has, are being taken seriously. The matter, which is the subject of assessment often reflects what is considered to be important in a school. In the study, it could be seen that the case schools can work more systematically on assessing students' qualities, skills and attitudes which are relevant to innovation, since these are important areas in terms of developing qualities that are relevant to creativity and innovation. Teaching in which content, working methods and forms of assessment pull in the same direction is a good foundation on which to build trust.

\subsection{Conclusions on How Schools Can Develop an Entrepreneurial Didactic}

We know a great deal about what results in short-term knowledge and a little about what is needed for knowledge to be retained. Together with, among other things, project-based learning, problem-based learning and investigative learning, pedagogical entrepreneurship is an approach to teaching and learning, which can help to accommodate the requirements of a highly developed knowledge society with a general regard to the ability to change, and with a particular regard to the development of creative knowledge, attitudes and skills. A school, which emphasises the importance of entrepreneurial didactics, will face a number of challenges in terms of developing students' creative and innovative attitudes, knowledge and skills:

1. The school must facilitate learning situations in which students are guided through phases characterised by alternately divergent and convergent approaches. Open tasks, problem-solving and scientific approaches will thus be a key requirement for this type of learning.

2. Since it is inner motivation that is most likely to result in creative and innovative processes and results, schools should facilitate situations, which are perceived as engaging, challenging, provoking or unsatisfactory to the student. From this perspective, it will also be a major advantage if the learning situations are perceived as authentic - i.e. closely connected to life outside the school.

3. Creativity and innovation must be implemented in many academic subjects - preferably across several subjects - and understood as an approach to the subjects and not something supplementary.

4. A vital point is that either too little or too much freedom could block creative and innovative thinking and problem-solving. If creativity and the capacity for innovation are to have the opportunity to develop, it appears necessary that the learning environment must create a balance between restrictions and freedom. It can achieve this for example through connecting ideas creation and new solutions to the development of new academic knowledge and skills which provide meaning in relation to the task, and by formulating the learning outcomes so openly that creativity and innovation are encouraged and are possible.

5. It is also important that the extent of freedom and restrictions must be evaluated on the basis of and adapted to suit students' experience and field knowledge, as well as their skills and qualities of relevance to innovation.

6. It is important for a school's forms of assessment to be adapted to ensure that creative processes and results are also the subject of rigorous assessment. Assessments should identify students' learning in relation to skills which are relevant to both creativity and innovation, domain-specific knowledge and skills, and task motivation

\section{REFERENCES}

[1] Amabile, T.M. (1983). The social psychology of creativity: a componential conceptualization. Journal of Personality and Social Psychology, 45(2), 357-376.

[2] Amabile, T.M. (1988). A model of creativity and innovation in organizations. I B. M. Staw \& L. L. Cummings (Eds.), Research in organizational behavior, 10 (pp. 123-167). Greenwich, CT: JAI Press. 
[3] Amabile, T.M. (1990). Within you, without you: the social psychology of creativity and beyond. In: M.M. Runco \& R.S. Albert (Eds), Theories of creativity. London: Sage.

[4] Amabile, T.M. (1996). Creativity in context. Boulder, CO: Westview Press.

[5] Andiliou, A. \& Murphy, P. K. (2010). Examining variations among teachers' and teachers' conceptualizations of creativity: A review and synthesis of contemporary research. Educational Research Review, 5(3), 201-219.

[6] Baer, J. (2010). Is creativity domain specific? In J. C. Kaufmann \& R. J. Sternberg (Eds.), The Cambridge Handbook of Creativity (pp. 321-341). New York, NY: Cambridge University Press.

[7] Beghetto, R. A. (2007). Does creativity have a place in classroom discussions? Prospective teachers' response preferences. Thinking skills and creativity, 2(1), 1-9.

[8] CDSL (Committee on Developments in the Science of Learning)(2001). How people learn. Washington, DC: National Academic press.

[9] Chappell, K. (2007) Creativity in primary level dance education: Moving beyond assumption. Research in Dance Education, 8(1), 27-52. DOI: 10.1080/14647890701272795

[10] Craft, A. with Dugal, J., Dyer, G. Jeffry, B. \& Lyons, T. (1997). Can you teach creativity. Nottingham: Education now.

[11] Cremin, T. \& Barnes, J. (2010). Creativity in the curriculum. In: J. Arthur \& T. Cremin (Eds.), Learning to teach in the primary school (2nd ed.). Abingdon: Routledge. 357-373.

[12] Dweck, C. (2006). Mindset: The new psychology of success. New York: Random house.

[13] European Commission (2010). Towards greater cooperation and coherence in entrepreneurship education. Brussels: European Commission.

[14] European Commission (2013). Entrepreneurship 2020 Action plan - Reigniting the entrepreneurial spirit in Europe. Brussels: European Commission.

[15] European Council (2000). Lisbon European Council 23/24 March 2000 - Presidency conclusions. Taken from http://www.europarl.europa.eu/summits/lis1_en.htm

[16] Gibb, A. A. (1993). Enterprise Culture and Education: Understanding Enterprise Education and Its Links with Small Business, Entrepreneurship and Wider Educational Goals. International Small Business Journal: Researching Entrepreneurship, 11(3), 11-34.

[17] Glaser, B. G. (1965). The constant comparative method of qualitative analysis. Social problems, 12(4), 436 - 445.

[18] Haara, F. O. \& Jenssen, E. S. (2016). Pedagogical entrepreneurship in teacher education - what and why? Icelandic Journal of Education, 25(2), 183 - 196.

[19] Hofstad, H. (2012). Håndtering av "wicked problems" $i$ kommunal planlegging: Lokal oversettelse av målsettingene om barekraftig utvikling og bedre folkehelse $i$ ulike planleggingspraksiser (doctoral thesis). Oslo: NIBR, Norwegian Institute for Urban and Regional Research.

[20] Karwowski, M. (2007). Teachers' nominations of students' creativity: Should we believe them? Are the nominations valid? The social sciences, (2), 264-269.
[21] Kennedy, M. (2005). Inside teaching: How classroom life undermines reform. Cambridge, MA: Harvard University Press.

[22] Krueger, R. A. \& Casey, M. A. (2015). Focus groups: a practical guide for applied research (5. ed.). Los Angeles: Sage.

[23] Kvale, S. \& Brinkmann, S. (2015). Det kvalitative forskningsintervju (3. ed.). Oslo: Gyldendal akademisk.

[24] Lackéus, M. (2013). Developing entrepreneurial competencies. An action-based approach and classification in entrepreneurial education. Gothenburg: Chalmers University of Technology.

[25] Lackéus, M. (2015). Entrepreneurship in education: what, why, when, how. Entrepreneurship360. Trento: Background paper for OECDLEED.

[26] Lackéus, M. (2016). Value creation as educational practice - towards a new educational philosophy grounded in entrepreneurship? (Doctoral thesis). Gothenburg: Chalmers University of Technology.

[27] Merriam, S. B. (1998). Qualitative research and case study applications in education. San Franscisco: Jossey-Bass Publishers.

[28] Moran, S. (2010). Creativity in school. I K. Littleton, C. Wood \& J. K. Staarman (Eds.), International handbook of psychology in education (pp. 319-359). Bingley, UK: Emeral group publishing.

[29] Runco, M. A., \& Johnson, D. J. (2002). Parents' and teachers' implicit theories of children's creativity: A cross-cultural perspective. Creativity Research Journal, 14(3-4), 427-438.

[30] Sagar, H. (2014). Teacher change in relation to professional development in entrepreneurial learning. (PhD Thesis). Gothenburg: Gothenburg University.

[31] Sawyer, R. K. (2012). Explaining creativity - the science of human innovation (2. ed.). New York and London: Oxford University Press.

[32] Scott, C. L. (1999). Teachers' biases towards creative children. Creativity Research Journal, 12(4), 321-328.

[33] Sternberg, R. J. (2006) The nature of creativity. Creativity Research Journal 18(1), 87-98.

[34] Strauss, A. \& Corbin, J. (1998). Basics of qualitative research: Techniques and procedures for developing grounded theory. Thousand Oaks, CA: Sage.

[35] Thomson, P. (2012). Creative school and system change. In J. Sefton-Green, P. Thomson, K. Jones \& L. Bresler (Eds.), The Routledge international handbook of creative learning (pp. 333-336). New York: Routledge.

[36] Vass, E. (2004). Understanding collaborative creativity: Young children's classroom-based shared creative writing In D. Miell \& K. Littleton (Eds.), Collaborative Creativity. Contemporary perspectives (pp. 79-95). London: Free Association Press.

[37] WEF (World Economic Forum) (2016). The 10 skills you need to thrive in the Fourth Industrial Revolution. Taken from https://www.weforum.org/agenda/2016/01/the-10-ski lls-you-need-to-thrive-in-the-fourth-industrial-revolution/

[38] Westby, E. L. \& Dawson, V. L. (1995). Creativity: Asset or 
burden in the classroom? Creativity Research Journal, 8(1), 1-10.

[39] Wiggins, G. (2012). Creative learning. In J. Sefton-Green, P. Thomson, K. Jones \& L. Bresler (Eds.), The Routledge International Handbook of Creative Learning (pp. 320-332). New York: Routledge.

[40] Yin, R. K. (2014). Case study research - design and methods $\left(5^{\text {th }}\right.$ ed.). London: Sage. 